David S. Lynch, MRCPI

Samantha H.Y. Loh, PhD

Jasmine Harley, BSc

Alastair J. Noyce, PhD

L. Miguel Martins, $\mathrm{PhD}$

Nicholas W. Wood, PhD,

FMedSci

Henry Houlden, $\mathrm{PhD}$

Helene Plun-Favreau, $\mathrm{PhD}$

Neurol Genet

2017;3:e188; doi: 10.1212/ NXG.0000000000000188

\section{NONSYNDROMIC PARKINSON DISEASE IN A FAMILY WITH AUTOSOMAL DOMINANT OPTIC ATROPHY DUE TO OPA1 MUTATIONS \\ OPEN}

Many genes implicated in familial Parkinson disease (PD) code for proteins with mitochondrial function. ${ }^{1}$ Several of these genes, including PINK1 and PARK2, are involved in mitophagy, a mitochondrial quality control pathway. ${ }^{2}$ We describe a family with 3 members affected by autosomal dominant optic atrophy in which 2 affected members also developed PD.

While the role of mitophagy-related genes in PD is well established, this report provides further evidence of PD risk conferred through abnormal mitochondrial fusion and cristae morphology.

Clinical description. Patient 1 (P1) developed visual impairment in childhood. She was severely affected by optic atrophy but otherwise well until age 70 years. She then developed depression, followed by asymmetric upper limb tremor. This was accompanied by postural instability and a bradykinetic gait. She was diagnosed with PD and has a moderate response to levodopa. Patient 2 (P2) developed visual symptoms at age 9 years and was diagnosed with optic atrophy. Her vision deteriorated in her $20 \mathrm{~s}$, but she remained well until age 40 years when she developed gait difficulty and upper limb rest tremor. She was diagnosed with PD and has a moderate response to both levodopa and dopamine agonists. During examination at age 53 years, she had Hoehn and Yahr Stage 2 PD. Additional features, such as dementia, neuropathy, or deafness, were not present in P1 or P2. The youngest sibling, patient 3 (P3), was diagnosed with optic atrophy at age 14 years, and while visually impaired, remained mildly affected and can drive and read without magnification at age 40 years. She does not fulfill clinical diagnostic criteria for PD at this time. See figure, A for pedigree.

Both P2 and P3 were clinically assessed using a test battery used in the PREDICT-PD study, a population-based cohort in which participants are risk stratified for future PD using a variety of determinants. ${ }^{3} \mathrm{P} 2$, who already carried a diagnosis of PD, scored 16/40 in the University of Pennsylvania Smell Identification Test (UPSIT),
Clinical/Scientific Notes

indicating anosmia. Her sister, P3, scored 33/40 in the UPSIT, which is within the normal range. A validated assessment of bradykinesia and incoordination, the BRAIN test, was performed by both P2 and P3. P2 scored in the low normal range for speed with a prolonged dwell time. She was also inaccurate and had poor rhythm. P3 scored in the normal range for speed, accuracy, and dwell time. These findings support the clinical observation that P3 does not fulfill motor criteria for PD, nor does she have objective olfactory or motor dysfunction that might suggest prodromal disease. She is, however, 10 years younger than her affected sister.

All 3 patients were found to carry the same heterozygous deletion of exons 28 and 29 of OPA1. We excluded point mutations in autosomal dominant $\mathrm{PD}$ genes via focused exome sequencing in patient P2 (Illumina TruSight One). Specifically, no rare variants were detected in SNCA, LRRK2, GBA, PINK1, PARK2, or HTRA2. An unrelated patient (OC) carrying a heterozygous frameshift mutation at the beginning of exon 28 (c.2708_2711 delTTAG) was used as a control. He was not affected with and had no family history of PD.

Methods. All 5 members of the family and patient OC underwent skin biopsy and dermal fibroblast culture. OPA1 protein levels were determined by Western blotting from whole cell lysates using the anti-OPA1 antibody (BD Biosciences), which recognizes both long and short isoforms of OPA1. Anti- $\beta$-actin was used as a loading control (Abcam, Cambridge, United Kingdom). Transmission electron microscopy (TEM) was used to investigate mitochondrial cristae morphology. Cells were fixed and imaged, and mitochondrial morphology was scored in a masked way in which a score of 3 indicated normal cristae morphology, a score of 2 indicated internal disorganization, and a score of 1 indicated mitochondria with severely damaged cristae. ${ }^{4,5}$ Mitochondrial networks were assessed in live cells after staining the mitochondria with tetramethylrhodamine and imaging at $40 \times$ under an Opera Phenix Microscope (Perkin Elmer, Waltham, MA).

Results. All affected patients showed an approximate $50 \%$ reduction in OPA1 levels by Western 
Figure Pedigree, immunoblot mitochondrial morphology score, and confocal microscopy images of mitochondrial networks showing representative cells

A

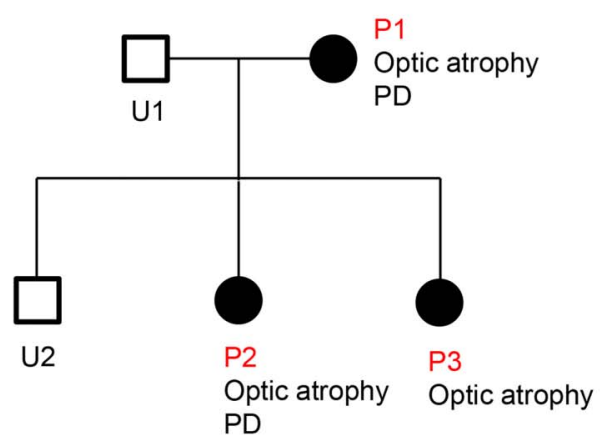

B

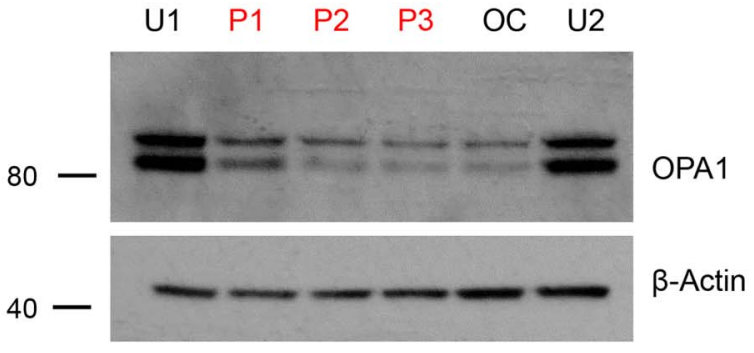

$\mathrm{D}$
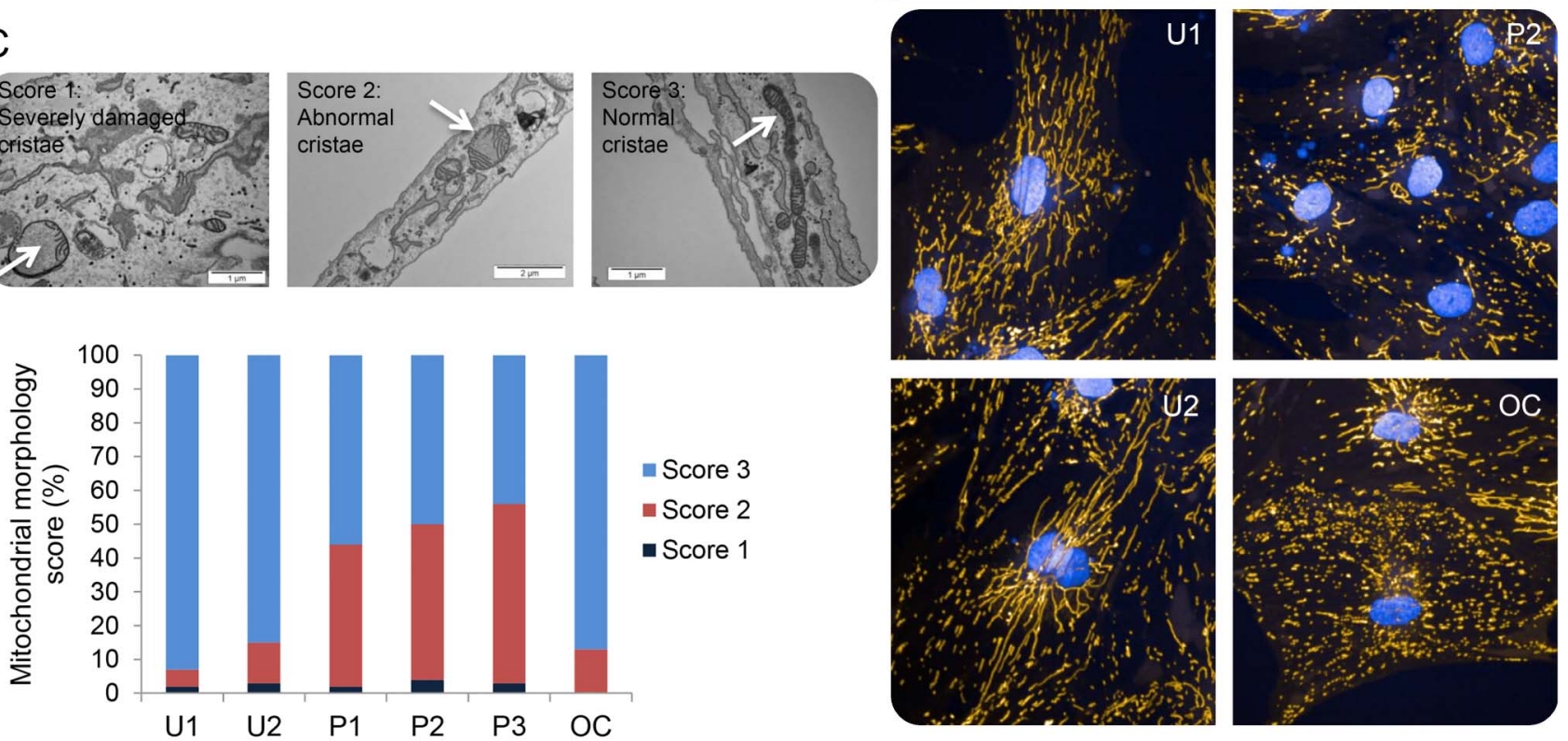
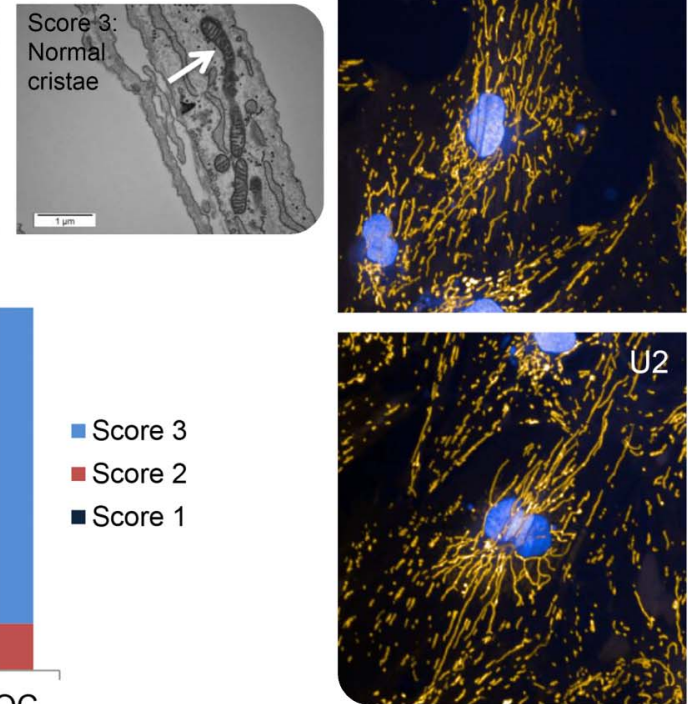

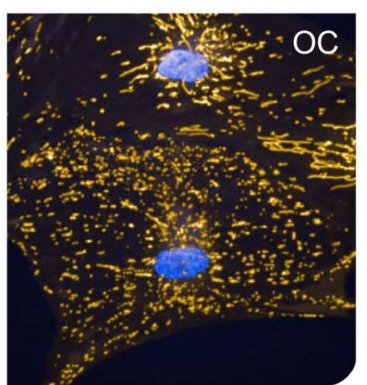

(A) Pedigree, in which filled boxes represent OPA1 mutation carriers. (B) Immunoblot demonstrating reduced OPA1 protein levels in all affected patients. (C) Mitochondrial morphology score demonstrating a significant increase in the number of abnormal mitochondrial cristae found in patients P1, P2, and P3. Examples of each score are shown using white arrows. (D) Confocal microscopy images of mitochondrial networks showing representative cells. OPA1 patient cells showed an increased number of fragmented mitochondrial networks compared with controls. PD = Parkinson disease.

blotting (figure, B), in keeping with haploinsufficiency. Examination of mitochondrial morphology by TEM revealed a significant increase in abnormal cristae in $\mathrm{P} 1, \mathrm{P} 2$, and $\mathrm{P} 3$, compared with their unaffected family members (figure, C). This phenotype was not shared by the unaffected OPA1 patient OC, despite all affected patients showing similar disruption of the mitochondrial network in live cell imaging (figure, D).

Discussion. Mutations in a number of nuclearencoded mitochondrial genes are known to cause $\mathrm{PD}$, some of which lead to dysfunction of mitochondrial quality control (mitophagy). In 1 previous report, a form of syndromic PD with dementia, neuropathy, and deafness was associated with OPA1 mutations. ${ }^{6}$ Dysregulated mitophagy and mitochondrial networks have also been detected in OPA1 patient cells. ${ }^{7}$ This report further implicates OPA1 in nonsyndromic, idiopathic PD associated with abnormal cristae morphology and mitochondrial networks.

From the Department of Molecular Neuroscience (D.S.L., J.H., N.W.W., H.H., H.P.-F.), UCL Institute of Neurology, London, UK; MRC Toxicology Unit (S.H.Y.L., L.M.M.), Leicester, UK; Reta Lila Weston Institute of Neurological Studies (A.J.N.), UCL Institute of Neurology, London, UK; and Neurogenetics Laboratory (H.H.), National Hospital for Neurology and Neurosurgery, London, UK.

Author contributions: David S. Lynch: study concept and design, acquisition of data, and writing the manuscript. Samantha H.Y. Loh: acquisition of data and critical revision of the manuscript. Jasmine Harley and Alastair J. Noyce: acquisition of data. L. Miguel Martins: interpretation of data and critical revision of the manuscript. Nicholas W. Wood, Henry Houlden, and Helene PlunFavreau: critical revision of the manuscript.

Acknowledgment: The authors thank the patients and their family for participating in this study.

Study funding: Funding for this work was provided by the Leonard Wolfson Experimental Neurology Centre, the Medical Research Council, and the Wellcome Trust. 
Disclosure: D.S. Lynch, S.H.Y. Loh, and J. Harley report no disclosures. A.J. Noyce has received speaker honoraria from Britannia Pharmaceuticals, Office Octopus, and Global Kinetics Corporation and has received research support from Elan Pharmaceuticals, GE Healthcare, Parkinson's UK, and LifeLab Online. L.M. Martins reports no disclosures. N.W. Wood has served on the scientific advisory board of Luxembourg Health; has served on the editorial boards of Neurogenetics, the Journal of Neurodegenerative Disease, and Progress in Neurology and Psychiatry; and has received research support from the Medical Research Council (MRC) UK and Wellcome Trust Parkinson's UK. H. Houlden has received research support from the Medical Research Council (MRC) UK, the BRT, the MDA USA, Muscular Dystrophy UK, Ataxia UK, Muscular Dystrophy UK, Rosetrees Trust, The Wellcome Trust, and the National Institute for Health (NIHR) UCL/UCLH BRC. H. Plun-Favrean reports no disclosures. Go to Neurology.org/ng for full disclosure forms. The Article Processing Charge was funded by the University College London.

This is an open access article distributed under the terms of the Creative Commons Attribution License 4.0 (CC BY), which permits unrestricted use, distribution, and reproduction in any medium, provided the original work is properly cited.

Received May 2, 2017. Accepted in final form July 5, 2017.

Correspondence to Dr.Lynch: David.lynch.13@ucl.ac.uk
1. Klein C, Westenberger A. Genetics of Parkinson's disease. Cold Spring Harb Perspect Med 2012;2: a008888.

2. Deas E, Wood NW, Plun-Favreau H. Mitophagy and Parkinson's disease: the PINK1-parkin link. Biochim Biophys Acta 2011;1813:623-633.

3. Noyce AJ, R'Bibo L, Peress L, et al. PREDICT-PD: an online approach to prospectively identify risk indicators of Parkinson's disease. Mov Disord 2017;32: 219-226.

4. Tufi R, Gandhi S, de Castro IP, et al. Enhancing nucleotide metabolism protects against mitochondrial dysfunction and neurodegeneration in a PINK1 model of Parkinson's disease. Nat Cell Biol 2014;16:1-12.

5. Lehmann S, Loh SHY, Martins LM. Enhancing NAD + salvage metabolism is neuroprotective in a PINK1 model of Parkinson's disease. Biol Open 2017;6:141-147.

6. Carelli V, Musumeci O, Caporali L, et al. Syndromic parkinsonism and dementia associated with OPA1 missense mutations. Ann Neurol 2015;78:21-38.

7. Liao C, Ashley N, Diot A, et al. Dysregulated mitophagy and mitochondrial organization in optic atrophy due to OPA1 mutations. Neurology 2017;88:131-142. 


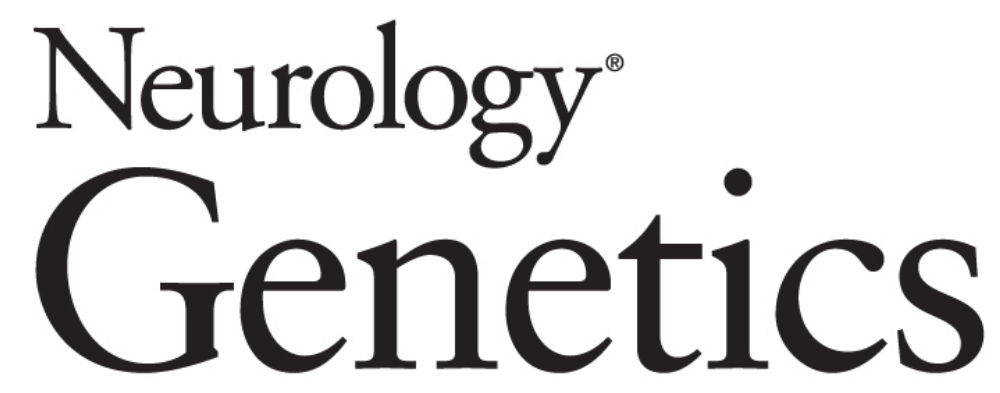

Nonsyndromic Parkinson disease in a family with autosomal dominant optic atrophy due to OPAI mutations

David S. Lynch, Samantha H.Y. Loh, Jasmine Harley, et al. Neurol Genet 2017;3;

DOI 10.1212/NXG.0000000000000188

This information is current as of September 22, 2017

Neurol Genet is an official journal of the American Academy of Neurology. Published since April 2015, it is an open-access, online-only, continuous publication journal. Copyright Copyright @ 2017 The Author(s).

Published by Wolters Kluwer Health, Inc. on behalf of the American Academy of Neurology. All rights reserved. Online ISSN: 2376-7839.

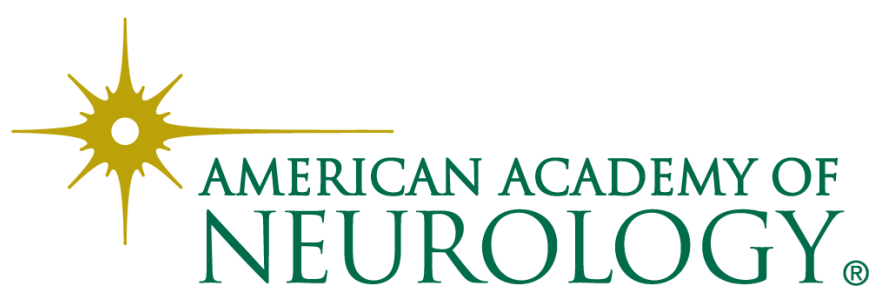




\section{Updated Information \& Services}

References

Citations

Subspecialty Collections

Permissions \& Licensing

Reprints including high resolution figures, can be found at: http://ng.neurology.org/content/3/5/e188.full.html

This article cites 7 articles, 2 of which you can access for free at: http://ng.neurology.org/content/3/5/e188.full.html\#\#ref-list-1

This article has been cited by 1 HighWire-hosted articles: http://ng.neurology.org/content/3/5/e188.full.html\#\#otherarticles

This article, along with others on similar topics, appears in the following collection(s):

\section{All Genetics}

http://ng.neurology.org//cgi/collection/all_genetics

Mitochondrial disorders

http://ng.neurology.org//cgi/collection/mitochondrial_disorders

Parkinson's disease/Parkinsonism

http://ng.neurology.org//cgi/collection/parkinsons_disease_parkinsonis $\mathrm{m}$

Information about reproducing this article in parts (figures,tables) or in its entirety can be found online at:

http://ng.neurology.org/misc/about.xhtml\#permissions

Information about ordering reprints can be found online: http://ng.neurology.org/misc/addir.xhtml\#reprintsus

Neurol Genet is an official journal of the American Academy of Neurology. Published since April 2015, it is an open-access, online-only, continuous publication journal. Copyright Copyright $\odot 2017$ The Author(s). Published by Wolters Kluwer Health, Inc. on behalf of the American Academy of Neurology. All rights reserved. Online ISSN: 2376-7839.

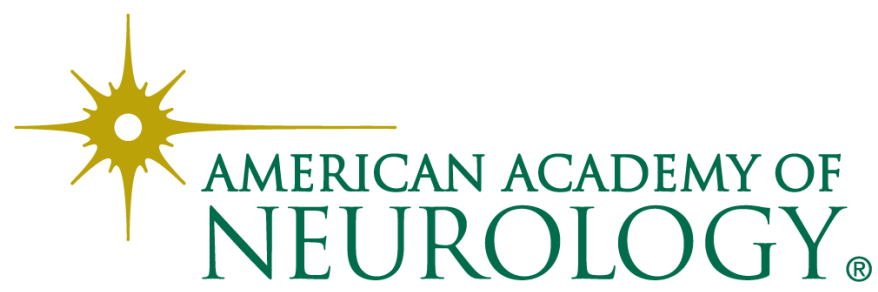

